\title{
TECHNOLOGY IN JAIN HARIVANSH PURANA: WITH SPECIAL FOCUS ON TRAVELLING BY AIR'
}

\author{
Dr. Alka Jain ${ }^{1 *}$, Sanyam Jain ${ }^{2}$
}

*Corresponding Author: -

\begin{abstract}
: -
Jagdish Chandra Basu proved through his experiments that all the plants and trees are alive and have feelings just like a human being has. He proved that plants react, laugh and also feel sad. This was proved in late ninetees. But Jain Agamas have been thesource of this information for last 2500 years.Acharang Sutra speaks a lot about 'Vanaspati Kayik Jeeva' (souls living in the bodies of plants and trees) and their feelings.The details are so live that one gets emotional for these so called non-living things.Not only vanaspati (plants) but prithvi (earth), Apkaay (water), tejas (fire) Vayu (air) are also alive as per Jain Canons. Unfortunately, modern generations do not believethese facts until and unless they are proved by some scientific approach. Hence plants are considered to be alive after Jagdish Chandra Basu's experiments, while other four types of Kayik Jeevas are considered to be non-living thing still now.

No one believed the stories of 'Pushpaka Vimana' in the Epic Ramayana as 'people flying in air' was not a scene that men of that era could imagine, but today we can see a large number of aeroplanes taking a lot of humans from one place to the other by air.

Though inclination of scientists towards Indian Hindu literature is appreciable who are exploring ancient scriptures of Hindus for old technologies and ancient theories with new searches and researches based on the information provided in ancient literature, but Jain literature has not been explored well till now while they have case studies of modern sciences like dream interpretation, medical sciences, colour therapies etc.This study attempts to explore an ancient Jain book 'Harivansh Purana' for case studies of air travel. The authors have listed and interpreted case studies from the book which give us a glimpse of flying technologies used in that era, users of the technolgy Further scope of this study can be to prove all the technological evidences in modern theories and references. Modern interpretation of these theories may bring out the truth that ancient Indian stories are not just myths, they have strong technological roots and evidences in their ancient literature Further Scope of Study can be to analyse the case studies in Harivansh Purana for other sciences and technologies also. The authors have focused on flying technology in Harivansh Purana but the fact is that the book is dotted with case studies of many other sciences and technologies like dream interpretation, medical science, architectural sciences, numerology etc. too. A list of armours used in the battles can also be listed. A list of sciences and technologies available in that era has also been given in the book like Pragyapti and maya etc. Experts of various fields should come forward to explore Jaina treasure of sciences for the modern world.
\end{abstract}

- *Lecturer cum Placement Officer, Subodh Institute of Management \& Career Studies, Jaipur **Lead Engineer, Samsung Research Institute, Bangalore

Keywords: - Jain literature, Jain technology, Indian technology, Harivansh Purana, Jain canon, Jain scriptures, Ancient Indian literature, Jain case studies, ancient case studies, Travel by air, Flying Technology

\section{(a) $(\$)$}




\section{RESEARCH QUESTIONS}

1. Do case studies in Harivansh purana have evidences of trvelling by air?

2. Were women also a part of workforce of this industry?

3. Was this technology open to all levels of the community?

\section{Research Methodology}

The ancient book Harivansh purana was studied by the authors with a focus on case studies which have evidences of air travel. The data was then analysed to study various features of this technology. In the end a conclusion is drawn with a hope that other Jain scriptures may also be explored for technological advances of ancient era.

\section{Harivansh purana}

There are three Harivansh Purana, available in Sanskrit, written by three different authors. For this study the authors have taken up Jain Harivansh Purana which was written by Acharya Jina sen - disciple of Punnat Sanghi KeertiSen. Harivansh Purana is a collection of life stories of 24 Tirthankaras (Great souls). Special details of three trithankaras are given, a brief history of other 21 tirthankaras is given. The story of Shrikrishna and Lord Arishtanemi - the two cousins has been explained in an interesting manner. In this reference we have a unique story of Jain Mahabharata which is slightly different from the popular Hindu version of Mahabharata.

\section{Case Studies in Harivansh Purana}

Harivansh Purana is a collection of stories/related stories of twenty-four 'Tirthankaras' (Gods) life. The authors are using the stories in Harivansh Purana as case strudies for the purpose of this research. These case studies are distinct glimpses of the technologies used by the people of that era. Travel by air was a common phenomenon in that ancient period.Almost each and every story has atleast one incident of people reaching their destination by air or through an aeroplane called 'Vimana'. In Chapter 12 , verse eight, while explaining the event of Sulochana's 'Swayamwara'

Aharya Jinasen says, "तत: स्वयंवरारम्भे प्राप्ते भचर खेचरू ”. Dr. PannaLal has interpreted the term ‘खेचरे' as 'ववद्याधर' while original meaning of खेचर is the one who stays in the space.

Hence we can say that these were the people who were human beings only because they used to marry human girls but they had a command on the technology of not only travelling by air, but also of staying in air at Vijayardha Hill.In Chapter 15 - verse 52 we find a case of a 'Deva' flying in the space with a man and woman." गरुड़वत्पररगह्य खमृ द्ययौ भरत वर् षु वरं प्रतत दक्षिणं”. In Chapter 19, verse 87 speaks about a technoly- चारण ररद्धध', this was a technology which made a person to be able to fly in the space.The term 'चारण श्रमणं' hints that only shramana (saints) were the occupants of this skill or technolgy. In Chapter 27, we come across a verse, “चद्रं ाभ खेचरं दृष्ट्र" also indicates that flying men could be seen in the space. It was not a rare scene, even if not a common one. Chapter 30 - verse 51 "खमस्क्स्त्यापनीत:प्राक्केनधचतु ९ खचरेण स:" explains how a flying man saves the king Vasudeva from the place where he was taken for slughtering. In the chapter 31 , verse 1 and 2 , there is again a case of kidnapping a king whom Soorpaka kidnaps by flying in the air"सपकषू ण हृत: शौरर्रुष धे स धचरेण खुे " and "जंघान मस्क्षित घातेन ववद्ववर्मु चाम् चत स खात् ". The verse explains how the kidnapped king struggles and the flying man drops him from the space. In the same chapter, verse four explains how the king is kidnapped again and dropped by the kidnapper 'Nilkantha' from the space, he fortunately drops in a pond and is saved. Another story explains a battle fought by the soldiers in the air. Chapter 47 - verse 102 - “तनगतष ोदर्श ष कामेन गगनस्थववमातनना" the flight could be

parked in the space. unfortunately today's modern aeroplanes do not have this advanced technology: “गगनस्थ ववमातनन:".Chapter 47, verse 125 explains how the prince Pradyumna flies in the space with his mother Rukmini .

b) Women Pilots : Women pilots can be seen in the stories taking men from here to there. In Chapter 30, verse 18 explains how Prabhavati comes by air and takes Vasudeva with her.Prabhavati was the pilot/Driver of the vehicle used for travel in the space by both of them "सा प्राप्तानमतत: प्रीता खमु स्क्त्र्प्य प्रभावती, ववद्याप्रभाव सम्पन्ना यथौ ववद्यु ददवोददता?" This verse explains that Prabhavati was a skilled and efficient pilot.

Another case from Chapter 34, verse 28 explains a case of a woman pilot defeating male pilots in a race :

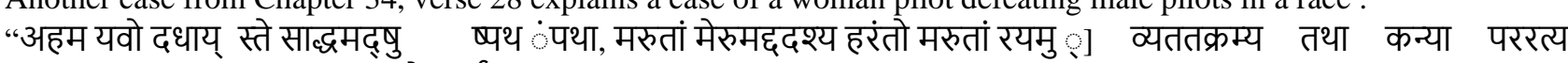
सरपवतषु म,भद्र शाल वने भ्यर्चय ष् स्क्जनाचाष:प्राक्म्यावततष ]]" Meaning those proudy boys flew in the space with a motive of reaching the 'Meru Hill' . Till the half way, they were flying together, but after this, the girl defeated them and made a circular journey of Meru, offered prayers to Bhadrashal and came back." In chapter 32 , vese 1, a case of a woman pilot is given :

"खावतीण ष र्भनन्द्यैका ददव्या ववद्याधरी धश्रता" who gets down of the plane she was flying. In verse fifteen she is shown taking Vasudeva with her and flying back.Chapter 32, verse 19 describes that a woman manufactured an aeroplane for Vasudeva and the princess Balchandra and Vegvati:

"ताभ्यां स्क्जगर्मर्रोस्तस्य शीघ्र शौयपषरं पु रमु, चक्रे वन्वती देवी ववमानं रत्भास्वरं " Acharya Jinasen has translated this verse

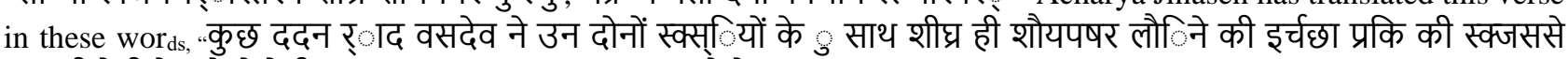
वनवती देवी ने रत्नों से देदीप्यमान एक व ववमान रच कर उन्हें दे ददया]'”This shows that women were not only flying the planes but they were well aware of the technology of making aeroplanes also. 
This can be a little advanced for today's world, but that ancient era had such educated and trained women workforce for this technology.

c) Cases of Air traffic : Verse 115 in chapter 56 beautifully discusses air traffic Chapter 56 - verse 115 air traffic. This explanation is given in the following words:

“आपयाषवायवषू गैगनषनजलतनधध वाहनानाम सम् है:ू सप्तानीकैरनेकैस्क्स्दिशपततणस्तं पररत्य प्रपेदे ]

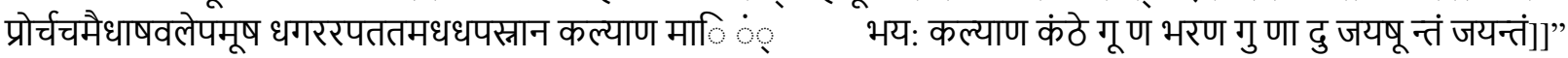

Meaning "The Indras fast speed vehicles and seven types of armies (seven types of Air force) filled the space (like a sea is filled) and took three rounds of the Hill Girnar. "Next two lines of the verse explain the height in the space where this traffic was seen, it was higher than the highest hill- Sumeru.

d) Battles in air : Chapter 47, verse 128 explains how the prince Pradyumna makes his mother Rukmini stand/stay in the air and and calls the enemies for a fight while standing in the space: " ववमाने स्थापतयत्वा तां युद्धाथ ंववयतत स्क्स्थत:" This reemphasises the fact that the aeroplanes or Vimanas could be parked in the space. Verse 132 is a case of a battle fought in the air. It describes the battle between Pradymna and Krishna which was fought in the space: "chk from sanskrit book" This case reemphasises the idea of parking in space.

e) Automated/Computerised aeroplanes : In the chapter 32 - Verse 21 showcases a case of automated aeroplane : "कामगेन ववमानेन सोडनेन वातनतासस्व:"meaning he flew with his wives in a plane which could travel as per his (Passanger's ) wish.verse 19 has already described that this automatic plane was manufactured by a woman, Vegwati.Verse 36 expalin that the plane had its own lighting system just like modern aeroplanes today : “आससाद ववमानं तर्चचारु संगीत संगतं,आश शौयपषु रं सु यवषु वमानार्मव मास्वरम" The verse also explains that music systems of that era were available in the plane. This case gives us a glimpse of highly advanced technology of aeroplanes which can be compared with modern planes for passengers with facilities of light and music etc.

F) All castes of the community used to travel by air : Many communities of the society like asura, kings, prince and princesses, Saints skilled with this technology, were using the facility of travel by air in Harivansh Puran era.Chapter 42 , verse 40 speaks of kings and princes and members of royal families using aeroplanes for commuting from one palce to the other fast "सो (वसुदेव)अवतीय षववमानाग्रादग्रजाम गरु र्नन्धवानु ,प्रणनाम् वप्रयाय् क्तःप्रनतः प्रणयात परै:?".

Case of Asura flying aeroplanes are also given in the chapter 42.Apart from this थेthe term 'चारण ऋद्धध धारी मतनु " has been frequently used in the book to describe the saints who could fly perhaps without a plane with the help of some kind of technology which could make them fly alone in the space.It seems that different communities used different technologies or levels of technologies to fly in air.Chapter 43, verse 225 explains Naradas coming here and there by air: " नारदोSवप स्क्जनं नत्वा प्रमोदें वशीकृत:समत्पत्य मरुन्मागु मेघकूंिे समाययौ]". In the chapter 47,

verse 83 we get details of Krishna's son Pradymna flying with Narada : “अथारूढो ववमानेन द्वाररका गमनं प्रतत”.In the verse 128, we see that Narada, Rukmini and Udadhi Kumaras are the users of the aeroplane and again their plane is parked in the space while Pradyumna is fighting.

\section{Limitations of the study}

The list of case studies is too long to be included in one resarch paper, hence only major cases have been taken up for this research while many more can be found.

Translation by Acharyas is adapted as it has been given, while at some places, differences were visible.

\section{Conclusion}

The authors have listed the case where historical characters are seen commuting by air.They have come across astonishing facts like automated planes, women engineers of the aeroplane technolgy, women pilots and air traffic in that ancient era .Modern pilots perhaps cannot park their planes in the space but our ancient pilots had this facility. The time has come when modern scientists should think on a level where they accept the facts given in Jaina scriptures rather than rejecting them as myths only. On a lighter note, Chapter 47, verse 76-77 and 95-98 show that today those so called myths are coming near the reality. Creation of an army by Pradyumna resemble the scenes of a recent movie 'Robot' where the producer has imagined that a robot can produce a cologned army of his own.

\section{References}

[1].Dr. Panna Lal Jain (Editor), Acharya Jinasen, 'Harivansh Purana', Bhartiya Gyanpith, New Delhi, 2003.

[2].Pandit Darbari Lal (Editor), Shri Jinasena Suri, 'Harivansh Puranam: Purvardham' Manikychandra Digambar Jain Granthmala Samiti,Mumbai.

[3].Pandit Darbari Lal (Editor), Shri Jinasena Suri, 'Harivansh Puranam: Uttarardham' Manikychandra Digambar Jain Granthmala Samiti,Mumbai. 